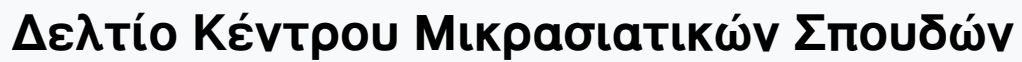

Tó 17 (2011)

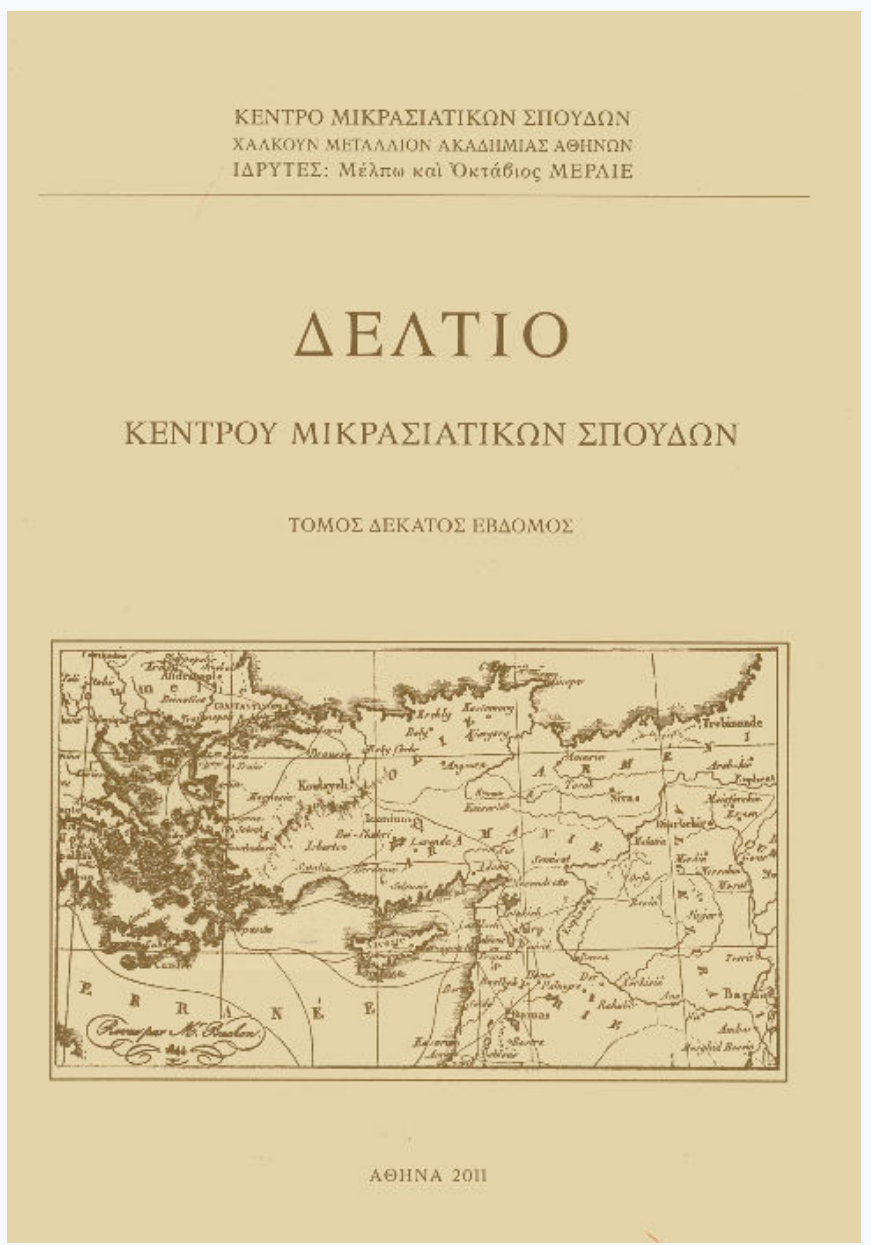

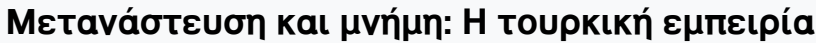

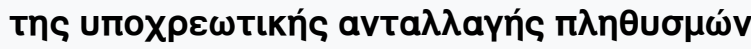

\section{Feryal Tansug}

doi: $10.12681 /$ deltiokms.17

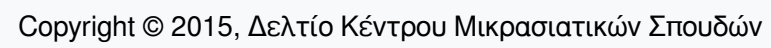

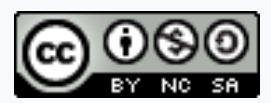

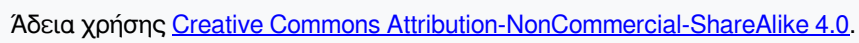

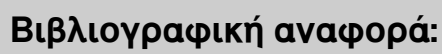

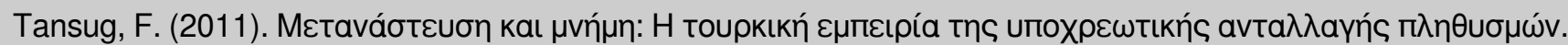

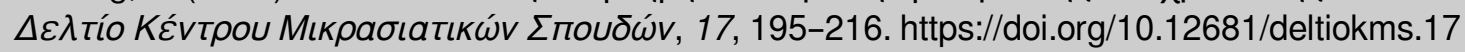




\section{Feryal Tansuğ \\ Memory and Migration: \\ The Turkish Experience of the COMPulsory \\ Population Exchange}

$\mathrm{F}$ ollowing the First World War, minority groups, particularly Greeks, Armenians, and, to an extent, Jews and Kurds, had to leave Turkey, while Muslim Turks, Bulgarians, Albanians, and Cretans had to migrate to Turkey, turning from migrants to refugees as part of the immense dislocation of the Great War and the Turkish-Greek War of 1919-1922. The Convention Concerning the Exchange of Greek and Turkish Populations was signed between Turkey and Greece on the 30th of January 1923, and was later integrated to the Lausanne Peace Treaty (24 July 1923). This convention constitutes a unique example of an internationally approved compulsory population exchange agreement of the modern age. Although it is difficult to know the exact number of people who fled to Greece and Turkey due to the exchange, the estimated number of Greeks who entered Greece between 1919 and 1923 is approximately more than 1,200,000 persons, ${ }^{1}$ and the number of Turks who left Greece is approximately $350,000 .^{2}$

Unlike the situation in Greece, in Turkey the compulsory population exchange is not popularly known. However, the recent academic ${ }^{3}$ and

1. Dimitri Pentzopoulos, The Balkan Exchange of Minorities and its Impact Upon Greece, Paris: Mouton \& Co, 1962, p. 69, 99. Kemal Ar1, Büyük Mübadele. Türkiye'ye Zorunlu Göç (1923-1925), İstanbul, Tarih Vakfı Yurt Yayınları, 2nd. ed, 2000, p. 177. It is important to note that these people did not leave for Greece after the population exchange agreement. The flight of people occurred in two phases: the first one during the withdrawal of the Greek army in 1922, and the second one between 1923 and 1924, after the Convention was signed.

2. Pentzopoulos, op.cit., p. 69; Arı, op.cit., p. 177; Renée Hirschon, Mübadele Çocukları, İstanbul: Tarih Vakfı Yurt Yayınları, 2000, p. 9.

3. Renée Hirschon (ed.), Crossing the Aegean: an Appraisal of the 1923 Compul- 
mass media ${ }^{4}$ developments in Turkey allow us to hope that nationalist biases in society will be abated. Since the 1990s novels have also been published about the compulsory population exchange. Regrettably, the Foundation of Lausanne Treaty Emigrants could not be established until 2001, 79 years after the exchange agreement. ${ }^{5}$

There are positive and negative assessments of the compulsory population exchange. While political and diplomatic perspectives regard it as a necessary solution to end the conflict between Greece and Turkey resulting from the clash of two nationalisms in the early 1920s, perspectives from the disciplines of anthropology, sociology, economics and international law have a more critical approach. ${ }^{6}$ The history of these events has been employed in the nation building processes of the two countries, ${ }^{7}$ influencing negatively people's perceptions of multicultural co-existence and generating 'otherness'.

sory Population Exchange between Greece and Turkey, New York and Oxford: Berghahn Books, 2003.

4. Apart from journalistic articles and articles flourishing in the printed media, there are also documentary films shown in film festivals and in local art and culture festivals. Some examples of documentaries concerning the compulsory population exchange are the following: Gökçeada: Land of Those Who Left, Came and Stayed, Neşe Ertürk, 48 min., in Turkish with English subtitles; Kalimerhaba Side, Savaş Güvezne, 55 min., in Turkish; Passing Drama, Angela Melitopoulos, 66 min., in German and Greek with English subtitles; Locket, Foreign Witness of Greek Republic, Mehmet Polat, 27 min., in Turkish; The Story of Both Sides of the Water, Büşra Köse, 23 min., in Turkish; Thinking of the Aegean, Enis Rıza, 160 min., in Turkish; Sorrow: Homeland of Separateness: Kayaköy, 26 min., in Turkish and Greek with English subtitles.

5. The Association aims to publicize the real picture of the Turkish refugees and exchange agreement by organizing conferences and meetings, by conducting oral history interviews with those who are still alive, and by encouraging academics to make researches on this issue. The association aims to contribute to cultivate peace between the two countries. Moreover, journalistic interviews with first generation muhacirs are flourishing in the printed press lately. İskender Özsoy, a journalist, published his interviews with first generation muhacirs in a two-volume book (İskender Özsoy, Íki Vatan Yorgunlar1, vol. I-II, Istanbul: Badlan, 2003). Kemal Yalçın published the interviews he took during his trip from Turkey to Greece (Kemal Yalçın, Emanet Çeyiz. Mübadele Insanları, İstanbul: Belge, 1998).

6. Hirschon, op. cit.

7. Ibid., p. 11. 
In this research, based on a small number of oral history interviews, I was interested, initially, in the way in which Turkish refugees perceive the Compulsory Population Exchange Agreement. In dealing with this question, I came across multiple representations of the Turkish Republic, which grew out of the experience. As will be seen below, the interviewees related my question directly to the Turkish State.

This study is based on the oral history methods of data gathering which I undertook in Istanbul and Izmir in the summer of $2003 .{ }^{8}$ It focuses on oral history interviews of four Turks from Ioannina, ${ }^{9}$ one from Kavala, one from Salonica ${ }^{10}$ and one from Crete. ${ }^{11}$ To identify the interviewees, I use the term muhacir, refugee. My interviewees also identified themselves as muhacirs, not as migrants, a concept that did not exist then as clearly as it does now.

In this article, I am at first interested in the Turkish refugees' popular sentiments about the compulsory population exchange. The major problem of Turkish national history is its ignorance of popular sentiments or experiences..$^{12}$ This article attempts, to an extent, to overcome this short-

8. This oral history project, with the title 'The settlement and perception of the Turks of Greece after the Lausanne Populations Exchange Agreement of 1923', was approved by the Ethical Conduct for Research Involving Humans, the Ethics Review Unit of the University of Toronto on the 16th of April 2003 (protocol reference no 9461). The preliminary results of this oral history study were presented in the Association of Nationalities Conference, «Nation, Identity and Conflict», Columbia University, New York, 17-19 April 2004.

9. Ioannina, the former Ottoman territory in the Balkans, in the northwestern Greece, fell under the Greek rule during the Balkan wars in March 1913.

10. Salonica was surrendered to Greece on the 26th of October 1912, during the First Balkan War (8 October 1912 - 30 May 1913), by a protocol between the Ottoman and Greek States.

11. Crete was given autonomy as a result of the 1897 Ottoman-Greek War (18 December 1897). It was officially incorporated into Greece as a result of the First Balkan War, by the Treaty of London, on the 30th of May 1913. Cretan Muslims were included in the Compulsory Population Exchange Agreement between Greece and Turkey, and, as a result, almost 30,000 Muslim Turks left Crete in 1923. Nükhet Adıyeke, Osmanlı Imparatorluğu ve Girit Bunalımı (1896-1908), Ankara: TTK, 2000, p. 198, 304.

12. Çağlar Keyder, 'The consequences of the Exchange of Populations for Turkey', in Hirschon, op. cit., p. 39-52. Until the early 1990s, newspaper articles and documentaries mostly published about the Greeks from Asia Minor who had 
coming. The use of oral narratives as a historical source might support official histories or might challenge them, depending on how historians reconstruct history from these narratives. Regrettably, we must not forget that the memoirs of the first generation, the parents of these interviewees, are absent from Turkish historiography and will remain so. They have all passed away. Today only their children survive, who came to Turkey during their childhood, and the children of the refugees who were born in Turkey in the early days of the Republic, and shared their families' economic sufferings in the places they resettled. The analysis of the memoirs of the actual first generation refugees might have been a very fruitful area to study if this chance had not been lost. My aim is not to analyze the memoirs of Turkish migrants who came to Turkey during their childhood, a field in which Social-Psychological Studies are specialized. I am aware of the historical/sociological divide on the role and use of memory as a source in historical research. Therefore, I am using Paul Connerton's differentiation between social memory and historical reconstruction. Professional historians utilize the historical construction method when they seek to identify traces of past events. Connerton indicates that historical reconstruction is independent from social memory, in the sense that what has been forgotten may be rediscovered by history. However, he also suggests that any historical construction may be strengthened by the social memory of groups, as in the case of oral history. ${ }^{13}$ This paper attempts to understand the ideological and political impacts on social memory, and to reconstruct the history of the population exchange by taking into consideration the ideological and political criteria. Therefore, as Ted Swedenburg notes, quoting from Taussig, 'my

to leave Turkey before and after the exchange. Interestingly, common people in Turkey are more interested in the Greeks from Asia Minor than in their Muslim counterparts. According to Damla Demirözü, there might be two reasons for this: First, the tendency of the people to see Greek-Turkish co-existence with a pleasant nostalgia. This is something that people make up in the way they wanted to see it. The second reason might be the desire of the Turkish intellectuals to relate Turks to the Western world through Greeks from Asia Minor, who are seen as the representatives of the Western world, and with whom Turks shared a history. See Damla Demirözü's article in this volume.

13. Paul Connerton, How Societies Remember, Cambridge and New York: Cambridge University Press, 1989, p. 13-14. 
concern therefore was not [so much] whether facts are real but what the politics of their interpretation and representation is'. ${ }^{14} \mathrm{I}$ am concerned with how people who migrated to Turkey between 1922 and 1924, and who were born in Turkey by first generation migrants, remembered the significant turning point in their lives, and with the relationship of their memoirs to the standard Turkish historiography. I am also interested in investigating their experiences of the forced migration and how their memories were affected by the dominant nationalist historiography and social atmosphere in their 'new homeland'.

The prevailing assumption regarding the settlement of refugees and impact of the population exchange is that the settlement of Turkish refugees was considered easier to solve because the number of abandoned properties of the Greeks from Asia Minor and other minorities was high enough to settle a relatively small number of incoming Turkish refugees. ${ }^{15}$ Recent studies based on archival data and interviews with muhacirs invalidated this prevailing assumption. They demonstrated that the impact of the exchange on Muslim newcomers to Anatolia was as detrimental as that on the Greeks from Asia Minor who were forced to move to Greece. ${ }^{16}$ They lost their livelihoods, suffered immensely during the resettlement process, and struggled to survive in Turkey. My interviewees also told me in detail how they and their parents suffered financially for a long period. Although the economic and social impact of the compulsory population exchange is beyond the scope of this paper, ${ }^{17}$

14. Quoted in Ted Swedenburg, Memories of Revolt: the 1936-1939 Rebellion and the Palestinian National Past, Minneapolis: University of Minnesota Press, 1995, xxvi.

15. Stephen Ladas, The Exchange of Minorities, Bulgaria, Greece, and Turkey, New York: The Macmillan Company, 1932; Pentzopoulos, op.cit.

16. Onur Yıldırım, Diplomacy and Displacement: Reconsidering the Turco-Greek Exchange of Populations, 1922-1934, New York and London: Routledge, 2006; Tolga Köker, 'Lessons in refugeehood: The experience of forced migrants in Turkey', in Hirschon, op. cit., p. 193-208. I agree with Tolga Köker who argues that the compulsory population exchange turned minorities into suffering refugees. My interviewees in their accounts also spoke in detail about their great suffering for years in Turkey.

17. For the economic and social impact of the exchange, see Arı, op. cit.; Ayhan Aktar, 'Homogenising the nation, turkifying the economy: the Turkish experience 
suffice it to mention that they could not obtain the equivalent of the properties and land they had left behind, and they were unfamiliar with the climate, land, and agriculture of the new territories where they settled. Focusing on their representations of the Turkish Republic, this study may contribute towards a better understanding of their nationalism, which might help to overcome nationalist attachments in dealing with issues of "other" and minorities.

The nationalist elite of Turkey preferred to construct history and national identity in an instrumental fashion, which is generally biased towards the modernization project, and treats individuals as passive recipients of their message. In the early days of the Republic, the state promoted identity, 'turkishness', and silenced the muhacirs, as their real 'turkishness' was already questioned by the natives as soon as they arrived. They were called, 'half infidels' ('gavurs'), 'fake Muslims', 'fake Turks', 'infidel seeds' or 'Muslims of Ali Pasha of Iannina'. ${ }^{18}$ Hence, their experiences and memoirs of their earlier homelands were left unvoiced in the early Republican atmosphere. In my case study of these Turkish forced migrants, no matter how much they suffered economically and socially, no matter how much they were humiliated by the native Turks and lost the social status they had in Greece, they willingly came to merge into the nation that they 'imagined'. 19

When muhacirs were asked: 'what did you know about Turkey when you used to live in Greece? Was it a place that someday you wished to move to?' the answer to these questions was negative. They had never seen the former Ottoman lands in Asia Minor which eventually became

of population exchange reconsidered', in Hirschon, op. cit., p. 79-95; Y1ldırım, op. cit.; Köker, op. cit.

18. KHT (second generation muhacir from Ioannina) explained the origin of this name as she learned it from her family: 'It is said that Tepelenli Ali Pasha converted Greeks into Islam forcefully in Ioannina. Therefore, Muslim Turks in Ioannina were generally called "Muslims of Ali Pasha of Iannina", meaning not "real" Muslim Turks'. KHT, Oral History Interview, 28 July 2003.

19. Benedict Anderson discusses why nations are 'imagined' and the motives to reach these 'imagined' nations. He asks: 'what makes the shrunken imagining of recent history generate such colossal sacrifices? So many millions of people willingly die for these imaginings'. Benedict Anderson, Imagined Communities. Reflections on the Origin and Spread of Nationalism, London and New York: Verso, 1989, p. 16. 
Turkey; they had never heard about the names of the cities in Asia Minor apart from Istanbul and Izmir, and they never had native Turkish neighbors or friends. Muslim Turks from Ioannina and Crete did not speak one word of Turkish, but they perceived the Turkish nation with 'deep and horizontal comradeship'. ${ }^{20}$ However, this perception became apparent when the Turkish defense movement was initiated in Asia Minor against Greek troops. According to the muhacir interviewees, the Greeks had their state, but the Ottoman Empire was dissolved, and the Turks needed their state too. 'If there is a Turkish state there, why should muhacirs have to stay with the Greek (Rum) ${ }^{21}$ anymore?' most of them said. In this context, when they were asked about their relationship with the Greeks, they did not remember any unpleasant events that they or their parents experienced before the occupation of Izmir by the Greek army. They remembered a peaceful social atmosphere, but distant social relationships between Greeks and Turks before the Turkish-Greek war of 1919-1922. The eldest interviewee RO (b. 1911, Ioannina) remembers their relations with Greeks in Ioannina as follows:

We had a nice and happy life in Ioannina. Both Greeks and Turks used to live in peace there. We lived under the Greek rule for 11 years. We respected each other's traditions, celebrations, bayrams, we would send them meat in the bayrams, and they would send us eggs in Easter. Greeks, Rum, never disturbed us until the war broke out. They respected our family very much there, especially my father. He was a much respected lawyer in Ioannina, he was a very religious, conservative and enlightened man. One night we woke up by the sound of the bells from the churches; except for my father, the rest of us were really scared; my father went outside, there were two outside gates in order to enter into the main house where we lived, he went to the very outside one to see what was happening; our [Greek] neighbor told him that 'don't worry İbrahim Efendi, don't worry, we took Izmir, now it is Bursa's turn'; my father replied, 'very soon, we [Turks] will take all of them back.' That night bad language was heard about Mustafa Kemal, they sang songs for Izmir, I cannot ever forget. But what happened, we [Turks] took all of them back eventually. ${ }^{22}$

20. Ibid.

21. Muhacir interviewees called the Greeks of Ioannina, Crete, and Salonica Rum. They did not make differentiation between continental Greeks by calling them Yunanl ("the one from Greece") and Greeks of the Ottoman Empire by calling them Rum.

22. RO, Oral History Interview, Istanbul, 7 May 2003. 
LK (b. 1914, Ioannina) says:

We were under the Greek rule for 11 years, before the war, we had very good relations, everything was fine. My father was a bank manager in the Agricultural Bank. I had many Rum friends, our relations were very good. But, all of a sudden, everything changed as soon as they landed in Izmir and started to proceed. All of a sudden they became hostile to us, especially during their withdrawal from Izmir, we could not breathe there, they insulted us so badly. Greek soldiers returned from the front without legs, arms. It was normal. How could they show us sympathy as before under these conditions? ${ }^{23}$

The fathers of LK and RO (bank manager and lawyer) were members of the exchange commission to organize the transfer of populations in Ioannina. They regarded leaving Ioannina necessary. RO spoke about how her father convinced her mother to leave, when her mother was scared to leave her homeland and make a long journey by boat:

Are you crazy? I have four daughters, am I going to let them become prostitutes here? What an inappropriate situation! You'll come; I'll give you medicine to make you sleep in the ship so that you won't feel anything during the trip. ${ }^{24}$

ET (b. 1920, Parga), ${ }^{25}$ whose father was an affluent tradesman in Ioannina running his small-scaled oil factory and whose mother was a primary school teacher, talks about his parents' good and close relations with Greeks. His parents were among those who did not want to leave Ioannina. When the exchange decision was confirmed and declared as compulsory, ET's father went to the north of Ioannina, to the Albanian border to change their nationalities in order for them to stay in Greece. ${ }^{26}$ But he could not achieve this. Greek officials came to their house while his father had left for the Albanian border and gave his mother a twentyfour-hour notice to leave Ioannina in his father's absence, so ET and his

23. LK, Oral History Interview, 10 May 2003.

24. RO, Oral History Interview, 7 May 2003.

25. ET, Oral History Interview, Istanbul, 16 July 2003.

26. The Greek state had allowed those who wanted to stay in Greece to do so on condition that they would change their nationalities to Albanian, French, British, whatever they wanted, except Greek. Noted by interviewee LK, 10 May 2003; for the religious and political criteria in the language of the Convention, see Ladas, op. cit., p. 378-383. 
mother had to leave the country within twenty four hours. In 1973, ET received a letter from one of his Greek friends from his childhood in Ioannina introducing himself and his family to him as being very close friends in Ioannina, and invited him for a holiday in his hotel.

VE (b. 1923, Salonica) came to Turkey when she was 1.5 year old, and grew up with her family's happy memories and good relations with their Greek friends and neighbors in Salonica. She mentioned her feelings about the Greeks:

Because of all those happy memories of my family I loved Greeks a lot, and because of this Greek love, I wanted to become a teacher in a Greek school in Istanbul when I graduated from teachers college. I applied to the Zapeion School [Greek School] in Istanbul, and I worked there with happiness and joy. ${ }^{27}$

Unlike VE and ET, other interviewees talked about the deteriorated relations between Greeks and Turks after the war. They were not as close as they were with their Muslim friends, but had a distant but respectful relationship. AE (b. 1928, Söke), a second generation Cretan whose family landed in Izmir before the compulsory exchange, stated:

I do not believe today's nostalgic stories about the Greek-Turkish relations. What I heard from my family does not match what I am hearing nowadays. Even though my father had a cigarette factory with a Greek partner and had extended business relations with the Greek community, people of both communities had distant social relations, they did not have any social relations outside business, they did not live intimately, but side by side. ${ }^{28}$

When Muslim Turks started to experience discrimination and became 'others' in their homelands as a result of increased Greek nationalism, they willingly moved to Turkey (except for ET's family) either before the exchange or under the regulations of the compulsory population exchange. They displayed the typical responses of being the 'other' in their former homelands under the Greek rule (except ET and VE). They called Greeks 'others' or 'the Greek' (Rum) with an unpleasant tone. Conversely, they admired the Greek culture and regarded it as their source of civilization. Particularly, female interviewees underlined this point:

27. VE, Oral History Interview, Istanbul, 9 May 2003.

28. AE, Oral History Interview, 20 July 2003. 
We really lived in civilization in Ioannina. When we came to Turkey the state offered us and some other Ioanninans land and houses in agricultural regions. We did not want this offer, nobody wanted it, because we came from civilization, we didn't know how to deal with agriculture. The Greeks were really very civilized people. We had their manners, it is normal, isn't it? People learn what they see in their childhood. Everybody liked us when we came to Istanbul, the newspapers wrote that Pendik turned into Paris, we were talking in Greek, our traditions were different. We didn't look like the other newcomers, we were different. ${ }^{29}$

However, their admiration of the Greek culture and people did not prevent them from seeing their Greek fellows as 'others' (except for two female interviewees). None of them recall any mixed marriages between Greeks and Muslims in their immediate environment. They said that this was something impossible, that everybody preferred internal marriages within the community. ${ }^{30}$ 'Mixing' with the Greeks was not something

29. RO, Oral History Interview, 7 May 2003. Similarly, VE and KHT described Greeks as civilized people, and their habits and attitudes were like theirs since they co-existed with them. Their parents had their civilized culture, and so did they. According to them, being a rumelili (to come from Rumeli) is a really different thing.

30. Three of the interviewees, KHT, VE, and AE, had a Greek grandmother and grandfather. When KHT learned that her grandmother was Greek, she was surprised and felt proud of it, although her father was very uncomfortable when she asked questions about her. He would say, 'but all Greek women who married to Turkish soldiers in Ioannina loved their husbands a lot, they became Muslims willingly'. KHT disagrees with her father: 'why you are hiding it, it is a good thing, and to convert them to be Muslim is not nice, imagine if it happened to us, it is not nice'. AE's maternal grandmother was a Greek from Asia Minor; however, he himself does not favour Turkish-Greek marriages. The dialogue between us:

FT: Your grandmother was Greek, how do you approach marriages between the two communities?

AE: I do not favour it, but one of my daughters married an English man, I did not approve, but she was above 18 , what could I do.

FT: What I meant was how do you approach Greek-Turkish marriages? If one of your daughters wanted to marry a Greek?

AE: No, I don't want it.

FT: But your grandmother was Greek?

AE: I don't care, I don't want it, and I would feel sorry. But, as I told you my daughter is now married to an English man, I tolerate it, although I do not approve of it.

VE's paternal grandfather was Greek and she is very proud of it. She calls her 
favorable for our families, they mentioned. They also expressed the sentiment that they were aware of the reality of Greek hatred toward Turks, which revealed itself openly during the advance of the Greek military campaign in Western Asia Minor.

As for the compulsory population exchange, they expressed their gratitude to the decision makers in Lausanne. According to them, the exchange was the success of Mustafa Kemal and his group and their memoirs were full of ideals of nascent Turkish nationalism. They were grateful to statesmen since they took them to the 'Turkish land'. RO stressed many times how appropriate the decision of the complusory population exchange was:

God bless him [Mustafa Kemal] that he took us to Turkish land. He did a very good thing, very good. We suffered a lot, but never mind, we were very happy that we landed into the Turkish land. When we arrived, we always celebrated the foundation of the Republic's day joyfully; I always carried the flags at school in Istanbul. What were we going to do among them [Rums], even if it was a wonderful homeland, what does it mean to be with them? Could there be a better thing than to step into the Turkish land? $?^{31}$

LK who left Ioannina at the age of 9 notes:

We really suffered an ordeal here (in Turkey), a great suffering. We lost all of our property when we came here. My father was a civil servant in Ioannina, bank manager at the Agricultural Bank, but at the same time, we owned a village there, therefore we had an enormous amount of wealth in Ioannina. But, if we had stayed there, what was going to happen to us? Was there any chance of survival for us there? Or were we going to be assimilated? When we think about these things, we are thankful for our condition now. We just saved our lives, this is what happened, we hardly stayed on our feet here

mother a 'Westerner' and she states that 'my mother raised us with Western traditions, I started going to theatres when I was in secondary school, we learned to read books, all these things are western traditions'.

31. RO herself has a bad memory of the Greek kids in Ioannina: when she was 12 , she was beaten by Greek boys because she was a Turk. She was very scared and had such a shock that she contracted malaria after this event. It took her two years to overcome it. She says: "in fact such things were not happening but that day by chance male kids of the other neighbourhood came to our neighbourhood I guess. In our neighbourhood such things did not happen before'. RO, Oral History Interview, 7 May 2003. 
with an immense struggle, as the state was newly founded, and it had nothing with which to support us. ${ }^{32}$

MF (b. 1919, Chrisoupoli (Sarışaban), Kavala),,33 in spite of being a strong admirer of Mustafa Kemal, showed some hesitation about the appropriateness of the compulsory population exchange.

We really suffered here, we lived in immense poverty, I could not attend school after secondary school, I worked in every kind of job, but when I think about it now, if we had stayed there, would it have been better? I don't think so. I am happy that we came. But, sometimes I think and I realize that ideas change, for example if I was asked this question twenty years ago, I would say no, it is not a good thing that we came here, but now, I am more comfortable. I bought this house, my children are university graduates, and therefore recently I have started seeing it as a good decision. But, the exchange was a really good thing for those who took advantage of the unorganized re-settlement procedures; those who were smart and canny made big profits when they came, they occupied all the big houses, empty lands in Darica. I was little, and me and my mother alone, we could not do anything, we did whatever people told us; people told us you are only two, so we took an abandoned very old house with four walls only, nothing more. ${ }^{34}$

In general, interviewees themselves talked about how they see the compulsory exchange without being asked. When they were asked openly whether it was a good decision or not, they directly referred to the Turkish representatives headed by İsmet Inönü at the Lausanne Conference. They said the decision was fine so that they could come here. RO states:

If Mustafa Kemal decided so it was necessary. ${ }^{35}$

\section{LK notes:}

I am still voting for the Republican People's Party, although it is the worst, I cannot act ungratefully, if we are here now, we owe this to them. ${ }^{36}$

32. LK, Oral History Interview, 10 May 2003.

33. Chrisoupoli (Sarışaban) district was a district in Kavala where Turkish was spoken. MF noted that they had no Greek neighbours or friends there, and they did not know a word of Greek. As he describes, it was a district populated totally by Turks.

34. MF, Oral History Interview, Istanbul, 13 May 2003.

35. RO, Oral History Interview, Istanbul, 7 May 2003.

36. LK, Oral History Interview, Istanbul, 10 May 2003. 


\section{ET says:}

The compulsory exchange decision was taken according to the desire of Atatürk. This means it was an appropriate decision. I adore Atatürk, I believe that he was a superhuman being, therefore I think his decisions and doings were not wrong. ${ }^{37}$

AE states:

Of course the exchange was a good thing, but in its application big problems occurred. It was a good decision; to live there was already not possible anymore. Is the life of people in Western Thrace a life today? At the same time, however, the exchange was a disastrous event in that it destroyed all Ottoman culture in those lands. ${ }^{38}$

Hence we see how they appropriated the Republican People's Party's (RPP) policy 'for the people' (the state is working for the people and knows better what is good for them), never 'by the people'. ${ }^{39} \mathrm{Al}-$ though they were critical of the resettlement policies of the Turkish State (this means the RPP, whose government ruled Turkey between 1926 and 1946 , the period known as 'the single-party period'), they automatically accepted the compulsory population exchange as an appropriate decision since Mustafa Kemal and his group decided for it. They never questioned the 'compulsory' nature of the exchange during their narration.

While they were talking about their approach to the compulsory population exchange, they themselves, without being asked, brought up present-day Turkey comparing it to the Turkey of Atatürk, in which they had grown up. This led some of them to deal with the rise of Islamic parties in Turkey and ruling of the Justice and Progress Party, whose leader and cadre is made up of former Islamist Welfare Party members.

37. ET, Oral History Interview, Istanbul, 16 July 2003.

38. AE, Oral History Interview, Izmir, 20 July 2003. AE states that the Greek Government purposefully kept the Turkish community of Western Thrace ignorant: 'It appointed them an ignorant imam who was not acceptable as a representative of Islam. He was the biggest religious ignorant fanatic. People had no right to choose their own imams there, the state decided for them. Here is what the state decided for them, to keep them in that ignorance'.

39. Şükrü Hanioğlu, The Young Turks in Opposition, New York and Oxford: Oxford University Press, 1995, p. 207. 
In this context we see how they perceived the Turkish Republic, what it meant for them:

In those years Turkey was not like today's Turkey. Now, Turkey is in such a condition that it is difficult to recognize. If this government does not change its mind about implementing its hidden projects, the military will stop them. This government is already under the strict monitoring of the military. When the followers of this government earlier openly acted against the principle of secularism, they were fired from their positions. But when this government came to power, it gave them their positions back. Atatürk entrusted this country to the youth, but the youth does not show any sensibility; therefore the military says that if you don't take care of this trust, I will do it. And it says I will not let the reactionaries or racist nationalists [he means the followers of the Grey Wolf Movement in Turkey] but I'll rule it. And I support them. I know that it would be very bad, if the rule of the country again goes to the hands of the military. But, it would be the best of the worst. ${ }^{40}$

MF talked about the same issue in the context of the veil:

My mother used to wear a veil, but it was a normal head scarf. It wasn't like today's particular types of veils. Each particular type of covering expresses certain relations and meanings nowadays, in our times there was no such a thing. I am a strong adherent of Atatürk. I always vote for the Republican People's Party, my mind does not understand others. I am his follower but not blindly. I am his follower because all of his actions and policies led to well-made and secure results, there was nothing wrong with them. ${ }^{41}$

$\mathrm{AE}$ is also strongly against rising Islamic trends in Turkey:

My grandfather had organized a band of outlaws with his friends when he came here. He and his friends were bandits attacking Greek farms and Greek bandits who would come from Samos (Sisam) island. They had a very hard time in Kuşadası and Söke. In short, they had done what they had learned from them in Crete. They applied the same things. My grand father's wife was a Greek, who converted to Islam, but he remained very hostile to Greeks. Later on, he and his two friends with whom he formed the band joined the Turkish Independence War. He was awarded for his service in the Independence War. My father was a nationalist, not a racist. For example, except my name, all my siblings' names are Turkish names. ${ }^{42}$ My father had a spirit of 'national forces' (kuva-yı milliye). I myself have no political idea in this Turkey. I do not approve of the politics of this Islamic government

40. ET, Oral History Interview, Istanbul, 16 July 2003.

41. MF, Oral History Interview, Istanbul, 13 May 2003.

42. AE's family was a Bektashi family. 
and these developments like the foundation of Imam Hatip schools. ${ }^{43}$ If these schools are going to train prayer leaders, they should not open more than enough. Moreover, why are they attending universities after Imam Hatip school, if they are decided to become preachers why do they want to become lawyers, bureaucrats or engineers? They get brainwashed in these schools, then, when they are placed in the high bureaucracy they act against the state policy and the principles of revolution. I do not vote the Republican People's Party either. Today everything is degenerated. Today, there is no real Bektashi. Atatürk did a good thing by abolishing sects and denominations. Otherwise, they were going to be degenerated as well. ${ }^{44}$

The muhacirs appear to be well adapted to the Turkish State's principle of radical secularism. Following the establishment of the Turkish Republic in 1923, the political elite, apart from being determined to conduct Western reforms, also attempted to secularize political life and society. The principle of democracy remained secondary to state secularism in Turkey during the nation building process. The six founding principles of the Turkish Republic excluded democracy, since the ruling elite was always suspicious that the sovereignty of the people would end up in the sovereignty of Islam. ${ }^{45}$ Like Southeastern European nationalisms, Turkish nationalism of the political elite having opted for ethnic premises created a concept of 'turkishness' to impose the idea of homogeneity on people remaining in the country. This imposition could be done through forming a national history. History is used effectively by the Turkish State to impose the national project, as in the case of many other nationalisms. For this aim, the Turkish History Thesis was formed in the First Turkish History Congress in July 1932. This new composition of national history had some problems: it required detaching the history

43. Imam Hatip schools are schools at high school level, which train mosque prayer leaders and preachers.

44. AE, Oral History Interview, 20 July 2003. Other interviewees also expressed a similar attitude against rising Islamic trends in Turkey. They are against them since they see them against the principles of Atatürk. Female interviewees expressed similar ideas in the context of the veil. They themselves do not use veil, but their parents did, except for the mothers of ET and KHT.

45. Göle Nilüfer, 'Authoritarian secularism and Islamist politics: The case of Turkey', in Augustus Richard Norton (ed.), Civil Society in the Middle East, vol. II, New York / Köln / Leiden: E. J. Brill, 1996, p. 19-20. 
of the Turks from the history of Islam and justifying the reasons for the Turks to have their own nation state in Asia Minor. ${ }^{46}$

During the First Turkish History Congress, the principles were determined about how the new nation should perceive itself and present its history to future generations in the rewriting of the textbooks. This was achieved without mentioning the ethnic diversity of the Ottoman Empire, and the disappearance of the Christian elements of the Empire. ${ }^{47}$ The main goal of the Turkish national project was 'to reach the level of civilized nations', which meant Western civilization. ${ }^{48}$ Moreover, in the nation building process, the political leadership attempted to break all cultural ties with the Ottoman past. Furthermore, the state exercised huge pressure and discipline from top to down not only to improve the economy ${ }^{49}$ but also to discipline its citizens with the idea that everyone works for the state and the state works for everyone..$^{50}$ The Turkish political interest of the 1930s was very hostile to diversity, liberalism, pluralism and individual interest. What it admired in the Soviet Union was not Marxism as a theory and ideology of the oppressed, but the strength of the state, its ability to impose its will on society, to exercise iron discipline in the cause of modernization. ${ }^{51}$ Eventually, the Turkish version of the nation building process with its secular and disciplinary project ${ }^{52}$

46. Halil Berktay, 'Dört Tarihçinin Sosyal Portresi' ['The social portrait of four historians'], Toplum ve Bilim 54-55 (1991), p. 28-31.

47. Reşat Kasaba, 'Kemalist certainties and modern ambiguities', in Reşat Kasaba and Sibel Bozdoğan (eds), Rethinking Modernity and National Identity in Turkey, Seattle: University of Washington Press, 1997; Soner Çağaptay, Islam, Secularism, and Nationalism in Modern Turkey, London and New York: Routledge 2006.

48. Reşat Kasaba, op. cit., p. 26-28.

49. Halil Berktay, 'The peasant in Western and Turkish History', in Suraiya Faroqhi and Halil Berktay (eds), New Approaches to State and Peasant in Ottoman History, London: Frank Cass, 1992, p. 109-185.

50. Ibid., p. 153.

51. Ibid., p. 146.

52. RO, who left Ioannina at the age of 13 , and her two years older sister had to attend primary school, although they were teenagers, in order to learn Turkish. She narrated how they learned Turkish: 'we were sitting in a corner of the classroom, they called as muhacir girls, we didn't know any Turkish. Then, when they realized that we cannot learn Turkish since our parents and aunts talked to us in Greek at home, they enforced a fine if we spoke in Greek. The principal sent an employee to 
under statism became quite successful. ${ }^{53}$ In this research, muhacirs who grew up under the influence of the Turkish nationalist project also show how influential this project has been.

Muhacirs do not want Westernization or Western culture to be challenged, because they appropriated it as the only real civilization. According to them, the Turkish Republic has definite principles and rising Islamic tendencies are against these principles. They expressed their disapproval and dislike of the political Islam by referring to Atatürk, not to their personal secular nature or their dislike of totalitarian religious systems. They equated the rise of Islamic tendencies to the danger of being ruled by an Islamic order, to which they are strongly opposed. The interviewees in this research reflected the general idea of most of the secular people in Turkey. The general idea of many secular Turkish people is that Prime Minister Tayyip Erdoğan uses dissimulation (takiyye): he hides his true intentions until it is the right time to reveal them. ${ }^{54}$ For the informant muhacirs, too, today's ruling Islamic party has hidden intentions of restoring Islamic order in Turkey.

In muhacirs' memoirs, there is no difference between the popular and the national memory, because what is popular was also national in the society of the emerging Turkish Republic. They perceive the Turkish State in accordance with the Kemalist ideology, regardless of their desperate economic conditions and the social turmoil in the new Turkish society. According to the muhacirs, they saved their lives when finally the Turkish nation was truly founded as a result of the Turkish War of Independence, and they were integrated into the 'nation' by the compulsory population exchange. They landed in the 'homeland' where they ethnically and religiously belong.

As for the idea of the 'homeland', in the Turkish literature on the exchange of populations, the notion of 'motherland' does not exist, unlike

our houses to tell our families about it, and also told the elder sister that they should also learn Turkish. We graduated from primary school when we were 17'. RO, Oral History Interview, 7 May 2003.

53. For the discussion on statism, state nationalism, see Berktay, op. cit.

54. Metin Heper and Şule Toktaş, 'Islam, modernity, and democracy in contemporary Turkey: the case of Recep Tayyip Erdoğan', The Muslim World 93 (April 2003), p. 160. 
in the Greek literature on Greeks from Asia Minor. In the Turkish case, the predominant idea is that of belonging to a powerful sovereign state..$^{55}$ Similarly, in my research, the muhacirs, unlike Greeks from Asia Minor, did not call the places they left 'homeland'. ${ }^{56}$ For the Muslim Turkish muhacirs, the important thing was to live under the sovereign Turkish rule with their co-religionists. However, we should not forget that the record of popular sentiments of the parents of these muhacirs, who were the adult first generation muhacirs, is missing in Turkish historiography. The homeland of their children, muhacir interviewees in this paper, became the Turkish Republic in which they grew up. Regrettably, we will never know what their parents, the adult muhacirs, would call their 'homeland'. All interviewees said that their parents could not live long, that they died in misery and silence in Turkey, particularly their fathers.

Forced population transfers, as one of the tools of modernity, were used in order to 'cultivate ethnic consciousness' with the aim of creating ethnically homogenous nation states. They became an expedient method of the demographic struggle for power for the sake of ethnic consolidation or dispersal. ${ }^{57}$ Several population exchanges that were conducted af-

55. Hercules Millas, 'The Exchange of Populations in Turkish literature: The undertone of texts', in Hirschon, op. cit., p. 221.

56. For testimonies of Greeks from Asia Minor see the publications and the Oral Tradition Archive of the Centre for Asia Minor Studies.

57. Milica Zarkovic Bookman, The Demographic Struggle for Power: the Political Economy of Demographic Engineering in the Modern World, London/Portland, Or.: Frank Cass, 1997. For the historical roots of the population exchanges see Joseph Schecla, 'The ideological roots of the population transfer', Third World Quarterly 14/2 (1993), p. 239-275. The idea of the population exchange was not new either for the nascent nation states in the Balkans or for Turkey. For example, an exchange protocol was added to the treaty of Bucharest (10 August 1913), which ended the second Balkan war, between Bulgaria and the Ottoman state. In this agreement it was stated that 'optional reciprocal exchange of the Bulgarian and Muslim populations within fifteen kilometers of the entire common frontier should be facilitated'. However, since a large number of people had already migrated during the Balkan wars, this agreement covered only a small number of the remaining inhabitants. See Ladas, op. cit., p. 18-19. Moreover, the Young Turks, who succeeded in establishing the exchange agreement with Bulgaria about the minority 'problem', aimed to achieve the same thing with Greece. On the 19th of May 1914 the clauses of the agreement between the Ottoman State and Greece were completed by the commission. However, the 
ter the First World War were modeled on the Turkish-Greek compulsory population exchange of $1923 .{ }^{58} \mathrm{Critical}$ approaches in political science, sociology, anthropology, and history are questioning international laws and the 'necessity' of the forced population transfers, stressing their human dimension, and evaluating them as one of the failures of modernity. However, from the perspective of the people who experienced it, like the Turkish muhacirs, the forced population transfer is something they liked and approved of, since it took them to their 'nation' or 'imagined nation'. In other words, they mythologized the Turkish State's ideology and policies so that they reconstructed it and gave meaning to this traumatic event in their lives.

In the final analysis, the narration of the muhacirs in this paper indicated the success of the Turkish national project, which imposed former non-Muslim entities of Turkey as suspicious 'others' over the homogeneous society they wanted to form. A generation grew up absorbing the nationalist discourse, which led to separation of peoples and alienation. This eliminated the possibility of mutual respect and understanding, and led to 'fear, suspicion, hostility and inability to

outbreak of the First World War suspended the activity of the commission, and this exchange agreement could not be effectuated. See Yannis Mourelos, 'The 1914 persecutions and the first attempt at an exchange of minorities between Greece and Turkey', Balkan Studies 26/2 (1985), p. 389-413. Furthermore, the Greek and Bulgarian governments signed a Convention Respecting the Reciprocal Emigration of Their Racial Minorities on the 27th of November 1919, on the same day the Neuilly Treaty was signed at Neuilly-sur-Seine; Ladas, op. cit., p. 27.

58. For example, between Germany and the Soviet Union; many Germans living in the territories occupied by the Soviet, such as Estonia, Latvia, Bessarabia, Lithuania, etc., were transferred to Germany. Also, the same applies to the population exchange agreement between Poland and the Soviet Union in 1944, and the exchange of populations between Czechoslovakia and Hungary in 1946. Robert M. Hayden, 'Schindler's fate: genocide, ethnic cleansing and population transfers', Slavic Review 55/4 (Winter 1996), p. 727-748. The Greek-Turkish case also constituted an example for the decision makers as a 'workable solution' to the India-Pakistan case. The exchange of populations between India and Pakistan in 1947 was the largest exchange of populations ever, involving more than 11 million Hindus and Muslims. Furthermore, the pattern of the Turkish-Greek population exchange was quoted in 1937 by the British Royal Commission on Palestine (Peel Commission) as a model that would solve the Arab-Jewish conflict over Palestine. Schecla, op. cit., p. 239-275. 
cooperate'. ${ }^{59}$ Furthermore, nationalist histories created and promoted the concept of 'other' that made conciliation and mutual understanding impossible. Nationalism attempts to obtain support from history to solidify its ideology. Therefore, history, with or without purpose, contributes to developing a sense of superiority for the group it favors..$^{60} \mathrm{In}$ this creation of 'other' a group prejudgment is produced with a negative tone. Official histories contributed to the alienation among citizens by attributing a sense of superiority to the dominant ethnic majority. Getting rid of the sense of superiority is crucial to abolish the prejudgment on 'others'. ${ }^{61}$ The source of the conflicts is not differences, but the superiority claims of the dominant ethnic majority or rule. If we could free superiority arguments from the 'other' discourse and render it to differences, it would be possible to understand the vitality and dynamics of multi ethnic and multi religious societies, which in turn would not only lead to peaceful coexistence, but also interaction. ${ }^{62}$

Turkish official history puts into the category of the 'other' not only Greeks, but also Muslim Turks who practice Islam as a religion and identify themselves with their religion. When a common 'other' is officially created, then that group builds up a sense of hatred against this exclusivist attitude. This creates tension and mutual fear in society. Hence, one of the tasks of the professional historians should be to question these superiority arguments and demystify their bases. ${ }^{63}$ Otherwise, national histories fed by the sense of 'other' will continue to contribute to more conflict and violence. The articulation of Turkish nationalism leads to serious consequences. In this context, it might be worthwhile to remember how ordinary people joined the government instigated attacks against Greek and other non-Muslim businesses and shops in Istanbul in 1955, known as the 6-7 September events. ${ }^{64}$ History constitutes the base for

59. Hirschon, op. cit., p. 10.

60. İlhan Tekeli, 'Tarih Yazıcılığ1 ve Öteki Kavramı Üzerine Düşünceler', in Ali Berktay and Hamdi Can Tuncer (eds), Tarih Eğitimi ve Tarihte 'Öteki' Sorunu, İstanbul: Tarih Vakfı Yurt Yayınları, 1998, p. 1.

61. Ibid., p. 2.

62. For the discussion of 'other' for both countries, see Berktay and Tuncer, op. cit.

63. Tekeli, op. cit., p. 5.

64. For the 6-7 September events and the deportation of Greeks of Istanbul 
politics. Therefore the character of history is crucial in a country. Historical writing itself could become understanding and changing of political discourses and ideologies. As a muhacir from Salonica states:

A garden is beautiful with all its fruits and flowers. Is there any garden with only one flower? ${ }^{65}$

\section{NOTES ON THE INTERVIEWEES}

RO has graduated from secondary school. She lives in Istanbul.

LT has graduated from secondary school and worked in various jobs in Istanbul. Finally, he worked in the State Railways Institution (Devlet Demir Yollari) for 16 years, from where he retired. He lives in Istanbul.

ET is a university graduate. He did an MBA in the USA. He worked as a high level bureaucrat in Ankara in the Ministry of Foreign Affairs. He lives in Izmir.

KHT graduated from high school in Izmir. She is a housewife. She is the spouse of ET. Their families have known each other from Ioannina. She lives in Izmir.

VE has graduated from Teachers' College (Öğretmen Okulu). She worked as a teacher in a Greek School (Zapyon Lisesi) in Istanbul. She lives in Istanbul.

AE has graduated from the Boarding Technical High School (Parasiz Meslek Yatıl Lisesi). He worked in the Turkish Military with a contract as a technician; he joined the Korean War, and decided to continue his father's profession of money-changing and jewellery. He lives in Izmir.

MF had to leave secondary school due to economic difficulties. He worked in various jobs. Finally he worked in a tobacco factory and became a tobacco expert; he retired from there. He lives in Istanbul.

in the following years see Dilek Güven, Cumhuriyet Dönemi Azınlık Politikaları Bağlamında 6-7 Eylül olayları, İstanbul: Tarih Vakf,, 2005; Alexis Alexandris, The Greek Minority of Istanbul, Turkish-Greek Relations, 1922-1974, Athens: Centre for Asia Minor Studies, 1984.

65. Quoted from İskender Özsoy, İki Vatan Yorgunları I, Istanbul: Baslan Yayınları, 2003. 
